

EAST \& WEST

Remember to Forget: Critique of a Critical Case Study ${ }^{1}$

\author{
Liu, $\mathrm{Xin}^{2}$
}

Department of Anthropology, University of California

United States of America

Keywords:

Maoist revolution, the life-world of everyday life, memory, retention, protention, narrative, history.

1 A Chinese version of the article has been published in the Tsinghua Sociological Review (2003), 308-42. A different version of this paper was first presented at the workshop "Imagining the Past; Remembering the Future: Twentieth-Century Asia," held at Cebu, Philippines, 8-10 March 2001; and later at the conference on "Modern Chinese Historiography and Historical Thinking" held at the University of Heidelberg, Germany, 23-27 May 2001. My gratitude first goes to Maria Serena I. Diokno and Susanne Weigelin-Schwiedrzik, whose hospitality and help made intellectual exchange a true pleasure. I also wish to thank the participants of those two workshops and, especially, the two discussants for my presentations, Diana Wong at Cebu and Tim Cheek at Heidelberg, for their valuable comments. Finally, I must acknowledge my tremendous indebtedness to Professor Shen Yuan, of Tsinghua University, whose friendship and intellectual stimulation were essential to the writing of this essay.

2 Xin Liu is Fellow of the Sociology Division, the E-Institutes of Shanghai Universities. He is also the author of In One's Own Shadow (University of California Press) and The Otherness of Self (University of Michigan Press). His most recent publication is an edited volume: New Reflections on Anthropological Studies of (greater) China (2004, the IEAS, UC Berkeley).

C Koninklijke Brill NV. Leiden 2004

Historiography East \& West 2:1 
Abstract:

The Oral History project, initiated and carried out by a group of Chinese scholars, is a sociological attempt in grasping the significance of the Maoist revolution for us today. This article, which is inspired by an interesting study of the Land Reform taken from the project, argues that a chief reason for the political victory of the Maoist revolution in China lies in its power for reshaping the relationship of the present to the past, that is, in the power of making a new mode of memory for the world of everyday life. In other words, it is not simply the material gains but a better story about what we can or should be, told by the Maoist revolutionaries that led to such a victory. It is this imaginative socialist story that grabbed the hearts and heads of ordinary people fighting for the future of the People's Republic. The key theoretical issues here are about memory and narrative; and these are discussed with reference to Husserl's philosophy via David Carr's formulation. 
關鍵字：

毛主義革命, 日常生活的生活世界, 回憶, 保持/保護, 叙述, 歷史。

摘要:

從為理解毛主義革命對我們今天的重要性來看, 這個由一個中國學者團 體創議與貫徹的口述歷史計畫可說是一個社會學上的嘗試。而本人在這 篇由上述計畫中一個有關土地改革的研究裡獲得霝感而寫就的的文章裹 認為, 毛主義革命在中國之所以能取得政治上的勝利, 主要是因為毛主 義在改造農民與過去的關係上的力量, 也就是說毛主義在為日常生活世 界創造一個新的記憶模式的力量。換句話說, 毛主義革命份子講述的並 不是怎樣簡單的獲得物質上的改善, 而是一個更好的有關我們能或我們 應該變成什麼的故事。就是這般社會主義的故事抓住了一般人民的心, 使他們為中華人民共和國的未來戰鬥。在此, 關鍵的理論上爭議是有關 回憶和 (流傳的) 敘述, 而這些爭議我在參照 David Carr 對 Husserl 哲學 的解說下有進一步的討論。 
Memory is a vehicle by which we travel in history. This is the assumption on which I have built my following analysis, which examines a case study on remembering the Maoist revolution in rural China. The main purpose of this paper is to reflect on the problem of memory, rather than focusing on the actual facts about what happened during the years of the Maoist revolution. In other words, this is an analytical exercise on the problem of memory through an anthropological critique of a case study about remembering to forget what happened during the years of the Maoist revolution. Presupposing that only the memories of violence can reveal the violence of memories is epistemologically handicapped. Hence, this paper must be read as an exercise of an analysis of memory, rather than simply an analysis of the revolution itself, though I do believe that the Maoist revolution remains one of the greatest intellectual puzzles for the social scientist. The case study was provided by Fang Huirong, when she was studying as a graduate student at the Department of Sociology at Peking University. Fang's work is part of a larger project, the "Oral History Project," directed by Professor Sun Liping, a well-known sociologist in China. ${ }^{3}$

\section{The Oral History Project}

In the last decade of the twentieth century, the significance of experiences of the Maoist revolution came to capture the theoretical attention of some (Chinese) sociologists. The problem of revolution was not a new one in other fields, such as history or literature, where we have continued to see interesting reflections on the experiences of the Maoist years. Sociology was a newly (re)established discipline of the social sciences in the 1980s, and the main attention of its practitioners, since it was reborn, focused on current social problems brought about by the Dengist economic reforms, such as emerging social stratification, unemployment, and so forth. Sociology as practiced in today's China has chiefly played a role in assisting the government to diagnose what has gone wrong and to prescribe possible solutions. The Oral History Project, in contrast, is a serious attempt to discover the significance of

3 Professor Sun has moved to join the newly formed Department of Sociology of Tsinghua University. 
the Maoist revolution and its continuing impact on society. This challenging project, unlike most sociological projects in China, does not aim at providing suggestions for further reform; instead, it hopes to reveal an alternative history as a means of understanding the meaning of life in the contemporary world.

There is a sociological assumption behind this project: apart from the official documents and archives, very little is known about the struggles of everyday life during the years of the Maoist revolution; and the Oral History Project was meant to retrieve - if such a term is proper - a moment of the past that has been lost from our vision. Official knowledge of what happened is never quite as "truthful" as it is claimed to be, because the problematic of "the life-world of everyday life," as it was called by some scholars of the project, was often brushed aside by the heavy strokes of the official history taking a grand view. Even if someone wished to write about this "life-world of everyday life," there would not have been room for such reflections, because the official history has been always written from the perspective of the Nation or the Party. What is revealed by the term "oral history" is precisely this attempt to create a different path to the recent past, that is, traveling to the past through another lane of memory. This other history has to be discovered now, at this very present moment in time, no later than now, because otherwise there will be no possibilities of revisiting the Maoist past by way of an oral history, due to the simple fact that those who experienced the radical years of the Maoist revolution are already in their fifties and sixties.

For such a project, nothing is better than taking up the task of examining the vast areas of China's countryside, where there is an immensely huge population and a great diversity of local traditions. What happened? What happened during the years of the Maoist revolution, while everyday life was filled with endless mass campaigns and political struggles? What is the impact of that recent past on today's China? Previous studies of contemporary China have certainly highlighted change, but the Oral History Project does not hope to report simply what happened in the past; instead, it tries to discover modes of existence and forms of power by redirecting our attention to the life-world of everyday life, taken as a problematic of socioanalysis; it means to question the revolutionary mode of social existence; to examine how a different form of power penetrated the world of rural life and gained 
control of it; and, in short, it asks: what is the mode of existence and the form of control in the revolutionary past by which we have become what we are? ${ }^{4}$

4 The general introduction to the intention and purpose of this project is printed on the front page of each research paper published under the project. The Chinese version of this introduction is much better phrased than the English translation, which contains a large number of grammatical mistakes, though the powerful message delivered by this brief declaration is unmistakable. Below is a copy of the English version (which I have not corrected in any way):

Our project is to collect daily life materials by using oral-history methods, to search for and research into the Chinese rural area's social change in the latter half of this century.

This century has seen China a particularly unusual century. In and through the intersection of turbulence and revolutions, which reflected in various levels and areas, some profound and lasting changes have taken place in China. Thus the traditional, rural society has stepped into the modern one. To record and study the history of period in detail contains no doubt far-reaching importance.

As we know, so many official written materials are available today, however, we find it is almost no oral data from grass-roots level, which is fundamental to study more concretely (and authentically, even the meaning of "truth" is increasingly open to question) on the transformation of Chinese Peasants' daily life. To fill the gap and open up the new respective, we hope this project will bring the true life and "history" back in. And the oral history is the best (of course not the only) framework for us to fulfill the plan and achieve the aim.

This project has two concrete aims: (1) Materials' collecting and collating. We want to lay a firm foundation for oral-history research on Chinese rural areas and peasants' daily life. Our project would produce several-thousand-hour tape recordings and written materials. (2) Describe and analysis the social life in Chinese rural areas during the latter half of this century. And we can reveal and interpret the cause of these transformation.

We plan to select six villages as our cases. They locate respectively in the Northeast, North, Northwest, Southeast, South and Central South of China. Our principal task is to interview deeply with the ordinary peasants and local grass-roots cadre, who have the personal experience of this period of transformation. In the meantime, we will collect extensively other related documents, photographs and material objects.

The span of period of our project's object as long as half a century. And the transformation of Chinese rural society undergoes several distinct phases during such a long time. Our project will be accordingly divided into six stages. The material-collecting work of every stage would be last [sic] for about three years. To say concretely, these stages are Land Reform, Collectivition. People's Commune and Great Leap Forward, Socialist Education Movement, Great Cultural Revolution, and Reform and Open. It is estimated that the whole project be last for twenty years. 
The Oral History Project has chosen a number of field sites, designed to cover as wide a range as possible of different places in rural China. Its main research method is the interview, that is, recording stories told by ordinary villagers of those chosen places. The choice of different locations, trying to spread them out as evenly as possible in order to include all major regions, was deliberate. The project was initiated in the early 1990s, and a number of what they called "working papers" have been published. These working papers, intentionally or not, have marked out a very different intellectual trajectory in which a series of questions, quite different in shape and nature from other sociological inquiries in China, were given powerful intellectual articulation. By saying this, I mean to emphasize that their work draws upon a different theoretical source, largely by their own reading of contemporary social theory, and is formulated in a very impressive and powerful style. ${ }^{5}$

In this essay, I do not intend to deal with these working papers as a whole; rather, I will use one piece of their work as an example to raise some critical questions about the nature of memory. The Chinese researchers' aim is to understand the life-world of everyday life in the recent past, to examine what they called "power practice" of the Maoist government, to raise questions about how rural life was penetrated by a new form of control and how that specific form of control was absorbed in life, and to look into the problematic of how a new inertia, a "habitus" if one prefers, based on the Communist ideology and organization, came into existence. The objective of their study, insofar as I understand their work, is to penetrate the surface of what has often been called state-society relations, to turn inside out, to research, as they said, into the experience of experiencing itself, the practice of power and the power of practice, by means of oral history. Such an intellectual agenda invites a series of further questions, one of which concerns the problem of memory.

\footnotetext{
5 Most of this research was done by a group of graduate students at the Department of Sociology, Peking University. I have read some of their "working papers." The first issue of newly established journal, Tsinghua Sociological Review, may be taken as an example of their intellectual approach.
} 
The Non-Event State: Truth in the Life-World

I will focus my analysis on Fang Huirong's work, published as Working Paper Series No. 1, by the Research Center for Oral History of Social Life, Peking University (1997), under the title of "Non-Event State" and "Truth" in the Life-World: Memories of Social Life of Xicun Peasants during the Period of Land Reform. This paper focuses on memory in the Hebei countryside. Fang's theoretical intention is to show how, in the process of state penetration into rural communities, a different mode of relating oneself to the past and others appeared. The question of memory is central to Fang's discussion: if the control of the Maoist government was effective, the reason is, Fang seems to suggest, that it succeeded in developing a technology of power practiced in such a way as to reshape how people remember or, more precisely, how they remember to forget. 6

6 The following is the abstract of the work in English written by the author, in which there are again some obvious grammatical and spelling mistakes, though the meaning of it is quite clear and consistent. This is a strict copy of the original and I have left all the language mistakes intact:

This thesis tends to analysis the profound and complex transformation of Chinese rural social life during the latter half of $20^{\text {th }}$ century, attempting to make use of a somewhat new perspective, namely mentality.

The main presumption is that, in traditional rural communities, the dominant type of memory about events can be called as memory in "non-event state". For the occurrence of events is rather highly repetitive, and for events there is lack of the precise location by institutional time, various events pile up and mix together without any specificable order, chronological sequels or intervals. In other words, all kinds of details or components of event(s) intersect and interpose one another in and(or) between event(s). Living in this state of memory, villagers would not "intentionally" specify a clearly discernible limits of event and identify a "true" event in some modern sense. To them the "truth" or "reality" is precisely those intersected and interposed events. In chapter 3 we try to discover the characteristics of memory in "non-event state" by analyzing "pouring out grievances" oral texts. Our conclusion is that it is the particular living circumstances in rural communities, which hardly need any condition to link several events and set up comparable relation (sequel and interval), that constitute this peculiar(?) state of memory.

A significant change during the latter half of this century is the increasingly common occurrence of events which beyond local level in rural communities [sic]. Then comes the demand to set up the comparable relations between so many ever incomparable events. Meanwhile, the setting up of relations should be closely 
To begin our analysis, let us follow closely the path of Fang's argument, which opens with the observation that the researchers were often mistaken by the villagers for cadres. This misrecognition, a remnant of Maoist revolutionary practice, as Fang later suggested, was doubtlessly developed in reaction to the endless, often contradictory, mass campaigns and political inquisitions during which outside cadres were sent into villages. Fang suggests that this misrecognition stemmed from a unique way of telling stories, whose events, small or great, cannot be (re)arranged into any coherent meaningful sequence on the calendar, which means that the peasants "could not establish comparable relations among different events, that is, they found it impossible to locate a local event in the historical process that is larger than what happened in one community". ${ }^{7}$ For instance, at one time there were more than thirty cows in this community but, from different stories told by people in this community, the researcher could not ascertain whether they had these cows in the 1930s or in the 1940s. The temporal reference, by which such events are supposed to be located in the process of history, is never clearly stated in the oral stories. The author knows that in 1953 there were 13 cows left in the village, but she could not be sure about what happened to the cows prior to that time, because the stories told about this simple event were always contra-

connected with two simultaneous courses: to achieve the ideological education on villagers by State, and to locate villagers in the new social classification. These processes are conspicuously reflected through two means taken by State to permeate its authority and power into village, which were all invented in the period of Land Reform. In chapter 5 we define the power of "investigate and research", the first means. And in chapter 3 we redefine the limits of latitudes of the second means, say "pouring out grievances". This thesis will take pain in discussing this two practices implying power [sic], to reveal the fundamental dilemma faced by these power-practices when they encounter rural communities (and, of course, not limit to the period of Land Reform). To say concretely, one side is the "event sense" in modern sense and correspondently "fact-reality", while the other side is the above-mentioned "non-event state" and its "truth" or "reality" in rural communities. And we should study the effect of this dilemma on rural communities' everyday life and mentality.

The materials are mainly based on our field work in Xi Village, Zunhua, Hebei Province. Apart from the oral texts, we have collected a lot of related documents in Zunhua Achieves [sic]. Using concepts from narrative analysis, we want to grasp the change of mentality in rural communities, which usually hard to study directly, by analyzing oral texts.

7 Fang 1997: 5. All translations of this text are mine. 
dictory and confusing. This is the beginning of Fang's inquiry. What lies behind this apparent puzzle is the modern assumption that time is always used as an external reference by which sequences of events can be established as objective and comparable. Fang cited Nobert Elias's discussion of time (1992) in order to set up her own framework of analysis, of which the key point is that, by establishing an external, objective sequence of time, an event is given its status of being an event, that is, its event-ness. In other words, it is locatable in time. Then an event can be said to have happened either earlier or later than another event. Following such a logic, the author considers the situation she encountered in the Chinese countryside as a "non-event state," because nothing is able to be separated from other events in time. The existence of this "non-event state" in the memory of the peasants is both the departure and the focus of her analysis.

Xicun (西村) is not typical of most villages in at least one respect. It was a model village during the Maoist years. In 1952 Zhao Xiguo, a Communist Party member, established a village co-operative, which was called and known as "the commune of the poor." This was highly praised by the Maoist government, and Mao Zedong himself once said that "the commune of the poor is the image of our whole country," by which he meant to stress that the Chinese people must struggle with what they had, rather than hoping to rely on others. Once Xicun was singled out, many people visited the village. Even today, as the author points out, there are still frequent visitors to this rural community. However, Fang maintains that Xicun nonetheless demonstrates the general character of the intersection of two modes of power practice the traditional and the revolutionary. ${ }^{8}$

In the second chapter of her work, Fang offers a reading of a text written during the Maoist years in order to discover the basic strategy of power practice employed by the Maoist government.. Essentially propaganda, this text was a village history of Xicun written by the Department of Literature

\footnotetext{
8 Fang 1997: 7. Fang's concern is not a particular power structure or the awareness of a power relationship; instead, it is the process by which power - that is, the power of a new state that was eager to change and reshape what was going on in the countryside - moves from the center to its outskirts. One may even say that what interests the author is the life of power rather than its (dead) bodies. In this way, we may call her subject "power practice."
} 
of Beijing Normal College. This was a very popular booklet receiving a first printing of 220,000 copies in 1976. The booklet opens with a quotation from Mao Zedong, which says that these very poor peasants, who owned only three legs of a donkey, formed "the commune of the poor" and struggled for three years entirely on their own to create their own wealth and means of production. "This must be the image of our whole country; and is it not possible for China, consisting of six hundred millions of such poor people, to become a prosperous and strong socialist country in a few decades?"'9 The last sentence of this quotation is a doubled statement, which Fang brings our attention to. On the one hand, "the commune of the poor" is an image of the country as a whole and, on the other hand, the whole country should be able to achieve what this particular rural community had achieved. This is not simply redundant; instead, it reveals a crucial strategy of relating a part to the whole. It contains a strategy of epitomizing, that is, to reduce the situation of the whole country to the image of one rural community; it also employs a strategy of amplifying, that is, to magnify a partial image to represent the future of the whole. To put it in sociohistorical terms, Fang suggests that this is a powerful means for situating the history of a local community in the larger picture of national progress on the one hand, and employing a local history as a metonymy for the historical process of the nation on the other. The point that Fang makes in this chapter is that the booklet is an excellent example of the Maoist attempt to build connections between the local and the national by means of installing a different mode of relating oneself to the past and the Nation.

Fang shows brilliantly how the Xicun history was written according to the time-map of a larger conception of the Nation that the Communist revolution had invented. Every event was supposed to be arranged according to the successive stages of the Communist Revolution. Such clearly identifiable stages included the Communists liberation of the people from the Japanese invasion, or the birth of the new China. The story of Xicun was told as if it were written from the experience of the people in the community, while in fact, as Fang correctly observes, the temporal references for village events were entirely drawn in terms of the official national calendar. If a specific

9 This translation of Mao's speech, which was made much earlier than the publication of this booklet, is also mine. 
event was supposed to happen according to the development of the national Communist victory but did not occur at the "correct" time, it would simply become "one day," or "a while ago," or "some time." For example, the story of a suffering villager was always told in such a way as to show that the Communist army saved his or her life, even if the suffering occurred after the Communist army had arrived. Contradictions of facts were thus disguised by "blurring" the temporal coordinates. Time could only be the time of the revolution; village events had to be fitted into this temporal scheme.

This being the case, Fang asks, why not simply write a history of the national revolutionary victory? Why bother to write village histories that struggled to match all the incoherent local events, which in any case did not make sense to readers of the day, to national/Communist time? The reason, as Fang rightly points out, is that the Xicun history reflected a particular mode of power practice whose aim was not only to record the history of the revolution but to transform the habits of memory in the countryside by creating a new form of relating villagers' experiences to the larger stages of the Communist victory. This booklet thus reveals a mode of power practice characteristic of the radical years of the Maoist revolution. And this particular mode of power practice, as those who have studied China know, relied upon the creation of a habitus called "speaking bitterness" or "pouring out grievances," which constitutes the central problematic of Fang's analysis.

Fang's inquiry also directs our attention to the problem of narrative. In a broad sense, her work is an analysis of the way in which stories are told by the villagers; in a more specific sense, Fang conceives of such narratives as an essential part of power practice. A fundamental question lying beneath the surface of her analysis concerns how individuals were supposed to be brought into the temple of Communist mythology. The term "mythology" is not used here to indicate that the Maoist government failed to transfer rural China; rather, it highlights its attempt to create a single story (or "myth") about the national victory of Communist China within which every single experience in different localities was to be rendered meaningful. In order to achieve this goal, as Fang briefly mentions, this mythological writing of history rests on literary imagery. It is not a coincidence that the Xicun history was written by the Department of Literature, rather than by a historian or a group of historians. As Fang argues, the history is full of metaphors and images of 
poor peasants struggling, led by and standing with the Communist Party, for victory, though it lacks specific dated events.

At the end of chapter 2, Fang draws our attention to a textual strategy resembling Mao's speech quoted earlier. An individual experience, such as suffering in the old society before the arrival of the Communist Party is described, and then the text jumps to a general, often sentimental, statement generalizing the condition of life for many people ("Is it not true that many of us, the poor and the oppressed, underwent similar experiences of suffering under the brutal rule of the Japanese?)." This textual strategy often began with a simple story about a single person's experience, and then the rhetoric would assume naturally, yet forcefully, a collective agency. Fang calls this a strategy "from the singular to the plural," which was key to the power practice known as "pouring out grievances."

In chapter 3 and 4, key to Fang's work, she analyses "pouring out grievances." Fang begins with the observation that in traditional rural communities there is often a pool of overlapping events that are not clearly stated with temporal references. For example, when a peasant woman was asked whether her mother-in-law treated her well, this woman usually could not single out a particular event or reply in such a way as to indicate her suffering happened in a specific time in her life. This woman might be able to say something about her mother-in-law being good or bad; however, as Fang insists, her comments were often so blurred as to become part of a large chunk of impression, if we do not wish to call it memory, from which no particular event or events could be distinguished as such. Although many events happened, what was to be singled out as a specific matter for grievance or "bitterness" had to wait for a hierarchy of social significance - some order of things, some meaningful political scheme - to be introduced.

There are two analytical aspects of "pouring out grievances." On the one hand, in order for grievances to be expressed, there must be something to be told, usually an event of suffering; on the other hand, there is this invocation of grievance or bitterness by the very act of speaking. The purpose of this speech-act is to cause both oneself and others to feel bitter about something, usually in the form of hatred toward class enemies such as landlords or rich peasants. Producing the emotion of bitterness resulted from telling a story about an event that occurred in the past, by which some sort of revolutionary 
significance was created for an audience, often including oneself. This involved, as Fang seems to argue, singling out an event from the non-event state of everyday impressions of memory. In order to say something about one's suffering, for example, one has to be able to say that, oh, in that particular year, my wife was sick, then I tried to borrow money from this particular landlord who anyway refused to give me anything, instead he tried to take away my daughter or my land ... . That particular year or this particular landlord has to be forced out of the blurred mass of the everyday status of things in order for it to be employed in the telling of such a story, which was necessary to produce bitterness. This analysis assumes that in the life-world of everyday life, there is a mass of unorganized events in the impression bank of memory; what makes an event meaningful is the singling out of it according to a pre-existing chain of significance.

In terms of how things are stored as impressions in memory, Fang suggests that the life-world of everyday life is made up of repetitive events that are not subject to temporalization. This is what Fang calls "non-event state" generally found in rural communities. There are some events that villagers do remember, such as marriage or harvest, which are what Fang calls "as if (they were) events". ${ }^{10}$ These "as-if events" can be divided into three categories. First as-if (A type), are events that mark a fundamental shift in the life of an individual from one "non-event state" to another such state. For example, marriage, which is of course significant, particularly to women, will be re-

\footnotetext{
10 I am confused by Fang's use of the term si (似) in Chinese, which I have translated into "as if", because Fang seems to argue that these are not proper events in comparison to those that happen in daily life; instead, they are grand things larger than events in terms of their significance. The logic for this use of the term will be clearer when we read on.

12 Fang provides some interesting suggestions about the experiences of marriage as a shift in life. For example, because, in most parts of rural China, the bride is supposed to move to her husband's family, women tend to remember their date of marriage much more clearly than men, who often forget when they actually got married, especially if they were still living with their parents when they married. Men tend to remember the division of family property, which marks a significant shift in the inertia of memory. Fang also observed that women tend to forget when they were re-married, because, for the same reason, re-marriage does not make a significant change in the life of their memories. They simply moved to another household; their activities of daily life remain remarkably similar.
} 
membered by the person involved. However, this shift, according to Fang's argument, does not change the individual's relationship to the non-event state; it simply marks a move into the sphere of a new non-event state. For example, in the case of a woman's marriage, she shifts from her natal family's non-event state to her husband's family's non-event state. ${ }^{12}$ The life-world of everyday life is different now, but the woman still does not take everyday events in memory as being organized according to a temporal sequence. More typical of this category of "as-if events" is the seasonal cycle, as villagers tend to confuse one year with another. Second (B type), are "unusual as-if events," such as a good harvest in a year of drought. Third (C type), are "historical intrusion events" such as invasion by the Japanese army and the like.

Peasant Narrative Strategies

After introducing the idea of "as-if events," Fang brings in another important concept, which she calls "narrative transfer." Fang notes that, "In reality, when 'as-if events' are turned into a 'non-event state,' they will obtain, in everyday life, a more durable and attractive life for themselves" (23). Put plainly, what Fang tries to argue is that "as-if events," though significant because they break the inertia of everyday life, cannot automatically extend or enrich their importance in the life-world precisely because they are already apart from it. They are cuts on the body of everyday life that demands these cuts to be transferred, so to speak, that is, made acceptable, to become an integral part of it. What Fang seems to be saying is that significant happenings are not significant in themselves simply because they are different from everyday life; what makes them significant is the telling and re-telling of these happenings. Their significance stems from their narration. The narration of these happenings is meant to bring about, according to Fang, a return to the "non-event state" in the life-world of everyday life, which eliminates the external temporal referent. This is what Fang means by "narrative transfer".

If such is the case, the actual narrating of these "as-if events" will become an important research focus, bringing our attention to the question: who is telling or re-telling "as-if events." The question of the narrator's identity 
brings us to an interesting phenomenon often seen in rural communities. That is, the person who had the original experience of some significant event may not be the person who tells the story about it. It is often the case, as Fang perceptively observes, that a person in a significant social occasion was unable to speak well and a listener from the audience (although not part of the original experience) would take over from the speaker the task of telling the story, often by making reference to something else in his own experiential world; in this case, the original speaker would simply become a willing member of the audience. ${ }^{13}$

There are a number of narrative strategies that good story-tellers utilize. Fang cites three such strategies. First, "stories with no immediate reasons for being so," which is a strategy of repetitive narration whose purpose is to bring an "as-if event" into the "non-event state," that is, to become part of the life-world of everyday life. Fang provides a detailed analysis of a Wang story collected in Xicun, which may give us some sense of what she means by this narrative strategy. For example, in one interview:

Question: Your family used to be OK, didn't it?

13 Anyone with field experience in rural China will have noticed this phenomenon. Asked why things are done in a certain way or why something happened, ordinary villagers often simply reply: "Yes, it is just like that." They cannot go on to give a detailed account of their own practices in many cases. On the other hand, some people are always known, in any rural community, to be good story tellers (called baihuo 白活 in Xicun), who can always provide an account of an event in an appealing way. This understanding of why the ethnographer is often baffled in the field is different from James Watson's account of "orthopraxy", which he uses to explain the refusal of the ordinary villagers in the New Territories, Hong Kong to speak more about funeral procedures, treating orthopraxy as a practical engagement with the ruling ideology without the ability speak about it clearly (Watson 1988). The concept of orthopraxy rests on the distinction between high and low culture, focusing on how common people try to incorporate the ideology of the ruling class in practice (see also Rawski 1988 for an argument against Watson's position along the same lines). Conversely, in Fang's account, the distinction is drawn between who is a good story teller and who is not; both are commoners participating in popular culture. The distinction between high and low culture is thus not a precondition for Fang's notion of narrative strategy, which provides a much better model in explaining how everyday authority is formed in smaller groups. Another merit of Fang's analysis is that the actual experience of experiencing is no longer at the center of analysis; what replaces it is the power of narrating. 
Answer: Family condition, well, nothing, nothing but not starved. He lost all in gambling, playing, let's say.

Question: All lost in gambling?

Answer: Well, my sister, found a mother-in-law for sixty dollars, all lost in Xinyemiao in the east, not a penny left-my mother saw not a single penny. My sister nineteen years younger than my brother-in-law. Ha-ya! Did this good thing! Not that I did not think of him. Nineteen years older - my brother-in-law than my sister, like selling her for it, to Chenjiapu in the east. ${ }^{14}$

Fang uses this example to show, as a strategy of narrating for getting into the "non-event state" of the life-world of everyday life, how immediate reasons for an "as-if events" are lost in the actual telling of it. The subject of the narration is a sister's marriage, but there is no account of any details such as the engagement, matchmaking, the negotiation of bride-price, and so forth; what is repeated in this telling of a significant event in life is, first, the age of the bridegroom, who was nineteen years older than the bride; and, second, the loss of money in gambling by the father. As Fang argues, this is a typical strategy in making a narrative transfer by which the immediate reasons behind the occurrences of the story disappear; thus the story becomes part of the "non-event state" in the life-world of everyday life.

It is true that, if one goes to the countryside, in listening to a peasant recounting his or her own story about the past, one would probably not be able to find all the details of time references or immediate reasons articulated for all actions. Therefore, even if we accept Fang's understanding of this case of how everyday memory works in the countryside, Fang still leaves open the question of the extent to which such an analysis is only a specific case of a more general phenomenon regarding the nature of oral communication in face-to-face contexts. This topic has been widely studied. ${ }^{15}$

14 This is a literal translation of the example provided by Fang 1997: 27, and I have tried as much as possible to keep the oral character of this interview.

15 Fang made no reference, for example, to Jack Goody's influential work on the consequences of literacy (1968), in which he discusses, in contrast to the power of words and letters, especially alphabetic writing, the limitations of oral communication in creating details, producing abstract analysis, and transmitting messages across time and space. To some extent, one may argue, while trying to follow the logic of Fang's 
However, the repetitions in such stories are not simply repetitions; they serve an important function. They highlight the images of suffering or what Fang calls "pouring out grievances." For the peasants, such stories have to become part of the life-world of everyday life by removing their reference to time and immediate reasons; what is left is an image produced in the telling by repetition; the use of this telling is to make one aware of the life-world in which one dwells, that is, to make oneself at home in the sense that one is aware of the world as it is. Fang thus gives us an account of how "as-if events" get transformed into part of the life-world of everyday life, that is, losing their temporal reference and immediate reasons in the telling of them. A crucial implication of Fang's analysis is that the way in which the state power penetrated the countryside during the years of the Maoist revolution encouraged, if it did not indeed compel, a habit of narrating and listening that favored "pouring out grievances." That is, stories of grievances may have existed for along time, but here it is important to note that the forces of the Maoist revolution, particularly its mass movements in the countryside, made this theme of the life-world of everyday life, that is, grievance or bitterness, so notable as to occupy the center of attention. This helps us to understand how the state power worked in the early years of the Maoist revolution: it worked by means of transforming the habit of listening and narrating in everyday life. This is a much better explanation for the success of the Maoist revolution than the conventional view that focuses entirely on the material benefits that the revolution brought to the poor peasant families. It is true that land reform was an incentive for the poor peasants to get involved in the revolution, but the justification for a new order of society had to come from somewhere else. It had to come from a change in the habits surrounding making sense for oneself. "Speaking bitterness" or "pouring out grievances" was a narrative form that built a bridge between a Communist vision of the future and an account of what happened in the past for oneself, explaining why one had failed to live a better life. Fang's work provides a good example of the creation of this narrative form: how Maoist power practices re-worked the habits of heart in the countryside.

analysis, that her discussion simply demonstrates, once more, some essential aspects of oral communication. 
The second narrative strategy of good story-tellers, as Fang shows, is to draw from sources outside the story that was being told about the life-world of everyday life. Good story-tellers constantly borrowing from other events and stories to augment the particular story they are telling, though for an outsider (an anthropologist auditor, for example), these borrowings may appear to be irrelevant to the telling of this story. What Fang tries to show is that when a story is told in everyday life, there is always a certain amount of information not directly linked to what is being told. For example, when a woman tells you something about her brother's death, which is an "as-if event," she might also tell you how she went to see a local opera, which is a popular cultural practice. This happening of going to watch an opera, at least to the mind of an outside listener, appears to be irrelevant to the story of the death of her brother. The point that Fang tries to make is that, because the "non-event state" of the life-world of everyday life is thus constituted, to make a story real and acceptable means to link to the unrelated chaos of events in everyday life. In some sense, one might say that to be real in this sense is to be chaotic, at least in accounts of events.

The third strategy of successful narration depends on producing vivid images in the telling of such stories. For example, the peasants created a large vocabulary of onomatopoeia used in story-telling that greatly affected their audiences. ${ }^{16}$ Such onomatopoetic words are not supposed to add more information to what is being said; instead, their employment is meant to provide an impression so vivid and real as to make the listener not able to forget the story.

Two significant conclusions emerge from this detour to analyze narrative strategies. First, the content of the "non-event state" in the life-world of everyday life tends to be undifferentiated. Some significant happenings in life become part of the life-world of everyday life by being told in such a way as to lose their "objective" temporal reference, being thus turned into the inertia of repetition related to other such events in life and predominated by the vivid imagery of everyday speech. Their significance can only be obtained by

${ }^{16}$ It is quite difficult to translate this kind of oral text from Chinese to English; and one also needs to note that there is a great deal of local variation in terms of what kind of onomatopoetic words may be used in different regions. 
the successful telling of a story; and such a telling is a way of bringing extraordinary events into the life-world of everyday life. Second, with the arrival of Maoist state power in the countryside, a shift in the habits of telling and listening occurred: both the narrator and the listener, consciously or not, developed a habit of a mental transference, that is, to read or hear a story in the singular mode of telling and/but to reach a plural understanding of it. A plural understanding of it means that the story heard or told is no longer understood as an individual's personal experience; instead, it has become an explanation for many people, usually the poor, working class people as a whole. If this view is correct, it helps explain the success of the Maoist revolution in the countryside in the 1950s and 1960s. The government was able to rely on what was familiar to the peasants, their way of narrating, to install an essential theme of the Communist propaganda, that is, to "pour out grievances" about the past. The Communists did not transform the life-world of everyday life in the countryside; they simply adapted it to their revolutionary purposes.

Fang's analysis is fused with the actual materials collected from Xicun, which is a major merit of her work: theory is not separated from the data. However, if one wishes to extend her analysis to other subjects, not directly related to the problem of Chinese peasantry, one may have to say something in an abstract fashion. Fang touches on two possible directions of further inquiry with regard to the larger problem of memory, the focus of this essay. First, a technical issue related to the question of creating memories by means of temporal or spatial associations. Fang's argument seems to echo a longterm debate in anthropology, in which "primitive" mentality is supposed to lack a conceptual grasp of temporal sequences, which are said to be essential to abstract thinking, while its mental association is fundamentally spatial in kind, as opposed to the so-called modern mode of thinking. ${ }^{17}$ Fang is not in fact essentializing the character of a rural mentality; however, her work does revive the question of space versus time in memory production. What Fang tries to show is that in the life-world of everyday life the dominant strategy of making sense to oneself is to repeat, that is, to remove an event from its

17 See, for example, Hallpike 1979 for a general discussion of the foundation of primitive thought as oral in character; see Wilson 1970 for a discussion of the problem of rationality in anthropology and philosophy. 
temporal anchor and to place it, together with many other such events, on the plain of "non-events."

If this is the case, a question may arise: how do individuals in such a lifeworld keep a sense of continuity in life? Or is this question adequate? What Fang seems to argue, if my reading is correct, is that peasants do indeed experience a sense of continuity in life, but this continuity is only possible when repetition is put into place. She is not talking about the sense of time outside a particular community; she is dealing with an internal clock, so to speak, that tells time of a different sort. This sense of time is characterized by repetition rather than a linear flow of minutes and hours, as experienced by those in urban settings. Fang provides some interesting ethnographic examples showing that it is not necessarily important to remember even one's age for a significant social event. The villagers tended to focus on the event or its image itself, not its relationship to time; what they received from the telling of their own stories was an impression of whether they were poor or not; it made little sense for an outsider, such as the interviewer from Beijing, to ask them, for example, when the Communists came, or when they bought a cow, and so on. The life of an individual, as Fang tries to argue, is not marked by a sequence of events in life; instead, it is represented by a jam of events impressed on the canvas of memory. The vagueness about time or temporal markers is not a sign of incapability to remember; instead, it shows a different understanding of continuity in life, which is better described as "a stretching out" that links one event to another in the life-world of everyday life.

Communist Narrative Strategies

In chapter five and six, Fang looks at the other side of the problem, how the Xicun villagers confronted the Communist officials who came at different stages of revolution to install the Communist order in their community. As is well known, in the early years of the Communist revolution, the Maoist government tried to reach the peasants by means of mobilizing the masses into a series of political campaigns. The "mass line" of the Party, as it was called, aimed to awaken the sleeping consciousness of the poor peasants, to bring their understanding of their sufferings to another level explicable only 
by class struggle. But how was such a task to be accomplished? How were the masses to be mobilized? The Maoist government trained their party members and sent what is known as "work teams" to each village to carry out land reform, which involved defining who was a landlord and who was a poor peasant. If we take the land reform as an example, the work team was supposed to, first of all, "lift up" the class consciousness of the poor peasants. A chief means of "lifting up" their class consciousness was for the team members to visit poor households and to listen to the stories told by poor peasants. This is not enough. In order to make Communist ideology a part of the peasants' world, the work team would carefully reinforce a certain pattern of telling or re-telling stories. In most cases, the work team was successful in helping peasants focus on the theme of grievance or bitterness, and then tried to show them how their stories were shared by all the oppressed people of China or even of the world. Fang's analysis helps us understand the means by which the mass movement was carried out successfully: transformation of the life-world by creating a new way of linking one's life to the lives of others. In doing this, the Communists built an imaginative bridge between one's suffering and the necessity for a Communist revolution. ${ }^{18}$

Another problem that the work team confronted was to how to define who belonged to what class categories. The Communists used five basic class categories:

Landlord: owns land and employs others to work on it;

Rich Peasant: although works himself, relies chiefly on the labor of others;

Middle Peasant: owns and works his land and occasionally hires others;

Poor Peasant: with little or without land, primarily sells his labor;

Worker: owns nothing at all and must sell his labor for survival.

But a variety of problems afflicted the task of giving everyone a class label. These categories were not so difficult to work out, they basically derived from

18 The existing literature on the mass movements has generally failed to address the question of how the communists were able to "lift up" peasant consciousness, though a good ethnography exists on the village-level processes involved in land reform. See, for example, Crook and Crook 1979; Hinton 1966; Potter and Potter 1990; Chan, Madsen and Unger 1992. 
a crude reading of Marx in the Chinese context. However, it was another thing when the work team had to fix every individual (or family) in the village with each of such class labels. One problem was how to draw the line between, for example, rich peasant and middle peasant, both of whom were supposed to hire others some time during the year, such as during a harvest season. How could one read the term "chiefly"? Another kind of problem concerned the period on which classification was to be based. Ownership of land changed hands quite often in the village. Even if someone was a landlord, disease might have forced him to sell his land for survival, which would have turned him into a poor peasant in a matter of months. If the class label was given according to the land one owned at the moment when the work team came to the village, some very poor peasants might be labeled as landlords simply because they had recently bought some land, a dream for every peasant. Conversely, landlords might try to avoid being so labeled by selling land just prior to the coming of the work team.

In reaction to these difficulties, the Maoist government worked out rough quantitative measurements. For example, it was decided that if one's income from exploitation (i.e. relying on the labor of others) was more than fifty percent of one's total income, one would be considered as a rich peasant; otherwise, one would be considered a middle peasant, whose land and other productive means were not supposed to be confiscated during the land reform. It was also decided that those who used to be poor but had recently bought land and other productive means would be considered poor or middle peasants (unless they owned their lands and other means of production for more than three years prior to the revolution). Fundamentally, the Maoist government declared that the population of landlords and rich peasants in the countryside was no more than ten percent, but they owned seventy to eighty percent of the land, exploiting poor peasants cruelly; whereas, the population of the poor and middle peasants, workers and other exploited classes was more than ninety percent, but they possessed merely twenty to thirty percent of the land. The government further claimed that this structure of inequality led to China's being invaded, repressed, poor, and backward. Land reform was thus central to the Communist ideology, which was simultaneously a general historical viewpoint and a numerically specific prescription. The struggle in each village was not only a struggle to define who was a rich peasant; it was also a struggle to link one's own struggle to the struggle of the nation. One 
consequence was that workteams and village leaders constantly tried to match local conditions to the prescribed numbers, finding at least one out of ten villagers to be landlords and rich peasants no matter what.

In some places, the Communist forces took control in the 1940s; while in other places their control was not consolidated until the early 1950s. The members of work teams were trained in different places and at different times, and their understandings of the year of the Communist victory differed. Even if quantitative measures were given by the government, individual labeling still faced numerous problems. What exactly did three years prior to the victory of the Maoist revolution mean? This lack of clarity produced endless struggles among the villagers, who tried to occupy a good place in the new social hierarchy. It is worth noting that the class classification, as an essential part of the construction of a Communist order of things in the countryside, was not a single occurrence. There were several rounds of re-checking of the initial classification in different areas of the countryside. For example, as Fang shows, as late as in 1963-64 when the Socialist Education Movement was carried out, ten percent of the class labels originally given in Xicun in the 1950s were changed. There was a long process of intra-village struggle in trying to gain new social and political capital when the Communist revolution arrived; and in such struggles there were endless use and misuse of memories and narratives in producing truth effects.

Fang argues that a crucial development transformed the relationship between the work team as the representative of the Communist power and the common people in the village. In the early stages of the movement, narrators were peasants, who "poured out their grievances;" the function of the work team was simply to encourage their "pouring out grievances" or "speaking bitterness" of the past. Later, when the class classification began, however, the work teams were no longer simply listeners of the stories told by the peasants; instead, they became the authority who decided how people should be classified In this second stage of the movement, the work team performed the role of an inquisitor, who was to ask questions about everyone's past and ownership. For example, who worked for whom in which year? For how long? Under what kind of circumstances? How much was he paid for his work? What was the percentage of his income coming from exploitation? These 
kinds of questions, however, were simply unanswerable. On the practical level, no one had ever considered the traditional system of exchange of labor among households to be exploitative But now peasants suddenly had to calculate whether someone's reliance on the contribution of another person's labor reached more than twenty-five percent, for instance. If so, one would be classified as a rich peasant, a deadly political label. Traditional forms of labor exchange might well not have been exactly equal, but neither could they be easily reduced to accurate figures.

Fang's larger point here is that two mentalities, one Communist and the other peasant, confronted each other in the process of "emancipation." With the introduction of quantitative measurements, the Maoist government tried to fix each individual in a (permanent) class position, which required the work team to figure out who sold labor to whom as well as who owned what property; however, these efforts became terribly confusing because a minimum understanding of time as a linear progression from days to months to years was an essential condition for the implementation of such quantitative calculations. This understanding the peasants lacked, not because they possessed no understanding of time but because their understanding, as established above, was based on a life-world where temporal markers were less significant than a sense of continuation produced by repetition, which is, so to speak, a thickening of that world essentially through a process of piling on spatial images. For example, at what age one did this or that, a simple question for the inquisitor, would have become highly complicated because people in Xicun had never before cared about it, although in most cases they tried hard to provide a "truthful" account of what he did at a specified time. Fang states that the officials were trying to find out the truth about each individual by means of reconstructing a temporal map of a person's life experience; however, they found so many different accounts, either from the same individuals on different occasions or from different individuals on the same occasions, about any person's life. This is not because, as Fang insists rightly, that they lied to the government; it is because it was impossible for them to make sense in the way in which they were required. They neither possessed the sense of time that was first introduced by the work team, nor could they quantify the work they did in the way that they were asked. The result of this conjuncture of two mentalities, as Fang prefers to call them, is that whenever a political movement arrived, there would be another round of re-checking of all the 
"facts" about each individual, particularly about the cadres in the village; and every time such re-checking of the facts occurred, different life stories were reconstituted. Peasant life is indeed plastic: it can be constructed in any way they themselves chose to or the inquisitor preferred to.

Chapter 7 is named "Pouring out Grievances and Joking" and reflects on the significance of singling out the theme of grievance in the accounts of the peasant's everyday life. Grievance, in Fang's analysis, had not been discovered or brought out to the surface of the life-world until the mass movements were introduced in the countryside. It is thus fair to say that "pouring out grievances" or "speaking bitterness" was a result of Communist power practice that strategically employed some essential features of the life-world of the peasants. The period of land reform, that is, from the late 1940s to the early 1950 s, was a time when such practices of power began to emerge. Soon it developed, in its own way and with its own rhythm, into a powerful means of mobilizing the masses. The condition of life in the countryside provided such a possibility; it was the Communist encouragement in the making of mass movements that created this particular form of narratives called "pouring out grievances." It was a historically contingent conjuncture of two forces that brought to the fore this feature of rural China.

Peasants, of course, told stories of suffering both before and after the land reform; however, the point is that it was through the period of land reform that this particular form of relating oneself to the past was established as a primary social and political norm. It became the only way of talking about the past, which was conceived as the darkness of the old society in contrast to the present brightness of Maoist governance. The intervention of the work team in effect created a "public sphere" necessary for any story-telling, which was in turn officially channeled to devalue the past in order to praise the present and to hope for the future. Any story-telling requires a public space for the narrator and audience to assemble. There are always a number of places in any village where people tend to gather and chat. The Communists' mass meetings were in fact producing such a public sphere through land reform. If a poor member of the community wanted land, he would have to come to the meetings organized by the work team. Landlords and rich peasants would be brought to such meetings to be criticized or beaten. What the work team controlled was the actual organization of power, and they were 
able to transform the habit of speaking and listening. Land reform, as a historical site of power practice, functioned to create a model of narration: "pouring out grievances."

After the mid-1950s, "pouring out grievances" was no longer at the center of the power practice of the Maoist government; however, it remained popular among the people themselves. Fang suggests that it became a means of creating a self-identity, though it had been invented to create a collective identity among the poor peasants. Fang seems to indicate that people could employ such a mode of relating oneself to others as a means of making sense for oneself, in ways no longer tied to the ideologies of the state. For example, this mode of narration might be used in complaining about the new order of society or even the Maoist revolution itself. Complaints became a habit of life. That is, a sense of self was very much embedded in the grievances that one was able to create and retrieve. Memory then became full of bitterness. This is, of course, not saying that there were no happy moments in the peasants' lives; rather, the sense of continuity required for living was predominantly formed by the habit of "pouring out grievances." Memory is not, and cannot be, simply memory; it has to be memory of something; this something in the case of rural China became painted in grievance. And whenever a new political movement came to the village - for example in both the Socialist Education Movement and the Cultural Revolution - grievances would be transformed into real forces in another round of struggles for prestige and power, often with deadly consequences.

With reference to the question of joking, Fang gives only a very short treatment, which bears, in my view, only one relevant point here. That is, almost no jokes were told about land reform in Xicun, because, as Fang suggests, it was dangerous to make jokes on a matter of such grave importance. After the establishment of this mode of "pouring out grievances" as a socially accepted and political correct form of narrating, people became very careful in their ways of talking about themselves and others, because everything they said, even as a joke, could bring dangerous consequences. The disappearance of jokes about land reform was due to the emergence of the inquisitional mode of power practice invented at that time, as Fang argues. 
Remarks on Fang's Work and Approach

The central problem that Fang is dealing with concerns the practice of the Communist power, which is indeed the major concern of the entire Oral History Project. These scholars offer a fresh take on many longstanding issues concerning the Maoist revolution. This new understanding has several advantages. First, Fang does not return to the conventional conceptual divides, such as that of society versus individual; her analysis begins with the life- world of everyday life, defined as an unconscious consciousness of one's own existence shown in the stories told about this world. Memory, or one's relationship to things past, occupies a central place in her analysis. By making reference to narrative strategies, Fang shows us a way of avoiding the old path that construes a dichotomy, always implicit in such studies, between psychological analysis of memory of individuals and sociological analysis of memory of societies. Historians and anthropologists are often reluctant to use psychological analysis, where the individual mind is the fundamental anchor of memory; they argue that the construction of memory by social or cultural or political forces must be considered. For example, one may argue that monuments or public ceremonies are instruments of collective or social memories; therefore, a detailed historical account of the emergence of such monuments or ceremonies would provide clues for an understanding of the function of remembering or forgetting in a social or a political setting. However, in my view, such a stance does not solve the problem of memory but simply shifts it to another level of analysis. Using this more sociological analysis, one is able to show how a political or a social force leaves its color on the traces of history; however, it cannot show how a mode of behavior or a habit of thinking comes into existence. What Fang's work demonstrates, it seems to me, is precisely this.

In terms of studying how things past are remembered, social scientists have tended to show the coexistence of several pasts and how they functioned to serve different interests for political or socioeconomic struggles. Two assumptions lie behind this approach: first, that plural spaces of memory allow different social or political groups to occupy different positions; and second, that the present struggle determines how their visions of the past are made and produced. Both statements are correct and useful, though neither is 
new. The question that Fang tries to pose is different. Let us take an example to illustrate this. Jing Jun's work on memory, The Temple of Memories (1996), describes how a lineage group in Gansu Province that claimed to be the direct heirs of Confucius struggled to maintain their own understanding of the past against the official version of it. One should note that, with the coming of economic reforms in the mainland, it was possible to make some counter-official claims after the late 1970s. Jing Jun introduced a powerful contrast between the story told by the villagers and the official version of the years of the Maoist revolution. The discursive space within which Jing Jun's discussion of the past and its memory was located is entirely dependent on the official/non-official opposition in thinking about the past. For example, with sympathetic eloquence, Jing Jun described how the village was flooded in 1960, under orders of the Maoist government, in order to build a major hydroelectric dam in the area. That moment of a painful past, stuck in the memory of common people, was unforgettable. Jing Jun is correct in arguing that there is another way of going back to the past, in terms of remembering and forgetting, from the point of view of the villagers. However, we must still ask whether the question of memory is simply a question of whose memory? It seems to me that in order to say something about what is remembered and what is forgotten, one must be able to say something about how a way of remembering or forgetting is made in the first place. By simply trying to focus on the politics of memory, as it is usually done and of which Jing Jun's work represents a good example, one cannot understand the nature of memory or the problematic of memory as a relationship of "ourselves" to the past. Memory is a vehicle by which we travel in history. By saying this, I mean to invite us to think about the nature of memory itself as a mode of relation, in and through which we are able to be what we are. It is a mode of relation that constitutes the very being of "ourselves". This is, in my view, a significant contribution of Fang's work, though not yet fully developed there: she focuses on the question of how a particular mode of memory came into existence during the early years of the Maoist revolution.

A number of theoretical possibilities are opened up by Fang's work. One is to link memory to narrative, that is, to consider the relationship of remembering to telling stories. Both remembering and story-telling are different from the remembered and the told, which, already being fixations of what is being remembered and what is being told, are often located in an officially 
designated social space. In between what common people say on daily occasions and what is recorded by the official world seems to be a true socioanalytical question, that is, the question of the extent to which the Communist power-practice during the years of the Maoist revolution transformed the way in which people remembered.. The key conceptual assumption in Fang's work is the inseparability of remembering from saying and vice versa. Memory is not a psychological status of an individual; nor is it a monument for the commemoration of collective events; rather, it is a practice of the relationship of "ourselves" to the past, real or imagined. Following this theoretical orientation, narrative analysis becomes an important means for the understanding of memory, and hence transforms the dichotomy of collectivity versus individuality. In my view, the attention to narrative provides a real possibility of understanding the intersection of the social and the personal. Stories, though told by individual persons, are always structured through language, which is by nature social. To pay attention to the significance of saying does not mean that one ignores or neglects the importance of real political or social forces. Fang has shown very well how the revolutionary forces were real in the sense that they produced indisputable effects on rural communities; these forces were virtually unavoidable and irresistible However, it is also important to note that the success of the Maoist revolution in the countryside relied on the creation of a different way of relating "ourselves" to the past, a different form of telling stories, a different mode of speaking and listening, which made the class classification and land reform possible.

A weakness in Fang's work, as I mentioned above, is that she seems to confuse some general characteristics of oral communication with the effects of Maoist power-practice. In order to deal with the problem of narrative, Fang has borrowed theoretical insights from literary studies, but failed to review, even in a note, the major literature on orality and literacy. ${ }^{19}$ Her works seems on occasion to be transferring arguments made by anthropologists and classicists about the nature of the oral versus written communication into an analysis of the intersection of two forms of narrating and remembering. It is not quite clear to the reader where one should draw the line between the culturally specific historical character of Chinese tradition in the country-

19 See, for example, Ong 1982. 
side and what is generally true of oral communication that characterizes many traditional societies. ${ }^{20}$ Fang's description of the "non-event state" (lacking temporal markers, numerical details, and abstract categorization) seems to ignore genealogical practices. Detailed genealogies are widespread in the Chinese countryside, representing a significant writing practice of family and lineage. They include meticulous descriptions of generations, names, dates and times, and numbers of marriages. Similarly, how can the concept of the non-event state explain the trouble that Chinese villagers often take in recording every single gift received at weddings or funerals?21 Fang's suggestive study is not yet complete if it is to represent a comprehensive view of peasant mentality. As well, in my view, Fang has failed to specify, as an effect of the Maoist power-practice in the countryside, what was specifically modified in the relationship of "ourselves" to the past.

My view is that, by emphasizing the significance of the life-world of everyday life, Fang is dealing with a particular kind of memory, rather than dealing with remembering the past in general. What is this particular kind of memory? What is the significance of it in articulating a relationship of "ourselves" to the past? How is it an essential part of the life-world of everyday life? Or is it?

In a sense, one may say that Fang has pointed to an interesting direction, she raised interesting questions, and provided initial but illuminating answers, but there seems to be a gap, a conceptual incompleteness, between what she poses as questions and what she answers. Tentative answers she has tried to provide are suggestive, but these answers do not correspond to the questions she has posed. I would venture even further to say that the illuminating suggestions in her work largely come from an intuitive reaction against the prevailing models of explanation in the fields of sociology and political science that tend to place too much emphasis on the interests and calculations of common people in the countryside as rational beings. She has correctly realized the flaws in this approach, but how one is to situate one's analysis systematically in the theoretical developments in the social sciences in recent

${ }^{20}$ For a discussion of political language and oratory in traditional society, see Bloch 1975.

${ }^{21}$ See e.g. Yan 1996. 
years is entirely a different question. One critical issue, which Fang fails to analyze, concerns the problem of time-awareness of common men in the life-world of everyday life. This is a problem that is linked both to the question of memory and to the analytics of narrative. Below, I will draw upon David Carr's reading of Husserl to try to provide an explanation of the problem of time-awareness in the life-world of everyday life. What lies behind the emergence of a new mode of relating "ourselves" to the past, real or imagined, is a change in the time-awareness in the world of experience. In other words, a change in our time-awareness, that is, not in the sense of conscious rendering of events according to an external frame of temporal reference but in the sense of a habitus of being in the temporal world, will change not only what is remembered but the way in which remembering occurs. If we still want to call this memory, this must be memory of a particular kind, that is, the kind of memory required in order for the present to be able to present itself as present, or what Husserl called "retention." It is essentially part of the present: the retentional presence of things past in the life-world of presence. I will argue, in contrast to Fang's approach, that what was transformed by the power-practice of the Maoist government was the retentional background of the present, which means that the Communist power-practice in the countryside produced a different mode of time-awareness for the common people and therefore reshaped the life-world of everyday experience. This is not arguing that the life-world of common people is essentially oral; it is saying that the shape of the present, that is, what comes to their focus of attention whenever such an attention is called upon, was transformed by the Communist power-practice. Peasants do remember according to the calendar, they do make abstract categorization, they do take things down in detail; what was changed during the years of the Maoist revolution was the background of their consciousness from which they were able to speak about the present experience of their situations. In short, they developed a different time-awareness that both negated the past and linked "ourselves" to the past in an innovative way. 
Reflections on the Problem of Memory

In this section I present a brief discussion of Husserl's notion of time consciousness, via a reading of David Carr (1986), which I hope will help us understand the nature of what Fang calls "non-event state."22

Husserl made a crucial distinction between two forms of memory: retention and recollection. Recollection is the usual sense that we use to describe what happened in the past: that which we can retrieve from the storage of our memory and bring to the consciousness of the present. This is re-collection. Retention is not the kind of past that lies in the storage of our mind; instead, if it were the past, it would be the just-past, that which serves as the required background for the present to be recognized as the present. That is, it is the past without which there is no way for the present to be identified as the present. For example, in the case of listening to a speech, each word uttered by the speaker must be able to be placed in a series of just-past-ness, otherwise, there will not be any possibilities for understanding the speaker's sentences. This sense of just-past-ness is different from remembering what, for example, Mao Zedong said fifty years ago. The former is retention, whereas the latter is recollection. This just-past-ness is singled out by Husserl to show the presence of the past in the present. It is essentially different from the normal sense of the past. That is, recollection is different from retention in that the latter is not the past of the past but the past of the present. As Carr explains:

The best way to understand retention is to turn, as Husserl does, to the comparison between the experience of space and the experience of time. Present and past function together in the perception of time somewhat as do foreground and background or focus and horizon in spatial perception. To see a thing is to see it against a spatial background which extends behind it and away from it and from which it stands out. Seeing always "takes in" this background as well as the particular object seen; that is, corresponding to the horizon is a horizon-consciousness that belongs to

${ }^{22}$ My reference to Husserl here is indirect, based on my reading Carr in which he elaborates Husserl's early work on the problem of time-consciousness. For Husserl's original discussion of the problem, see Husserl 1964. 
every perception. Just as there is no object without background (and no background without object; the two notions are correlative), so there is no perceptual consciousness of space which does not include horizon-consciousness. Now Husserl says that the temporal is experienced by us as a kind of "field" like the visual field: the present is its focus and the just-past forms the background against which it stands out. Consciousness of the present always involves retention as the horizon-consciousness of this background. ${ }^{23}$

The spatial metaphor is crucial. The present cannot be present unless it is set in the background of just-past-ness. This immediate or primary past is not the past as we usually understand it, something behind us in time, but part of the structure of the present which makes temporal perception possible. The same can be said about the future: expectation in the normal sense, which means to call to the mind some sort of future event, a birthday party for example, is different from the primary expectation or anticipation, that, to parallel retention, may be called protention. The distinction between expectation and protention parallels that between recollection and retention. "Taking past and future horizons together, then, one may speak of the temporal as a 'field of occurrence,' in which the present stands out from its surroundings, and of our consciousness as a kind of gaze which 'takes in' or spans the field in which the focal object stands out". ${ }^{24}$

What needs to be pointed out here is that when Husserl talks about "field" or "horizon," dealing with time-consciousness through the employment of a spatial metaphor, he does not take space as the objective space of geometry; instead, he takes it as "lived-experience"; that is, as it is well known in the phenomenological tradition, the latitude of intentionality, which is the structure of experience that is not reducible to the experience itself. ${ }^{25}$ The spatial image of a field or a horizon is so employed as to show that there is an orienta-

23 Carr 1986: 21-22.

${ }^{24}$ Carr 1986: 23.

25 See, for example, Merleau-Ponty's classic, Phenomenology of Perception (1962), for a discussion of the significance of perception for the phenomenologist, as well as the difference between the objective space of geometry and space as lived-experience. For a short introductory treatment of the basic phenomenological concepts, see Sokolowski 2000. For a survey of the turns and twists in the phenomenological movement over a century, see Spiegelberg 1994. 
tion toward the future, not simply that the future is presented as a chain of events which one anticipates; instead, Husserl means to stress the openness and interconnectedness of the nowness with its immediate past and future, that is, as a field of lived-experience or as a horizon of past-present-future from which the now stands out to be the focus of that horizon. The fundamental point, with reference to the metaphor of space, is that "the temporality of an experience of a temporal object is not itself an object but a structural feature of that experience". ${ }^{26}$

As Carr argues, the Husserlian idea of retention-protention as a horizon from which the experience of the very present moment stands out, provides a possible solution to the problem of experience. It is against this horizon that the very possibility of now is possible, and a temporal whole is assumed within this now-ness. Action is not only meaningful when it is completed but already meaningful when it is being acted out, because an immediate retention and protention is involved in the now-ness of an experience. Carr's discussion emphasizes that, even the pre-configured human experience - the very basic mode of simple everyday action - already contains a temporal structure, a certain sense of past-present-future. This argument challenges the usual conceptualization of human experience as devoid of any structure, let alone narrative structure.

Carr argues for the narrative nature of the human experience, which is not our chief concern here. My purpose in introducing him is simply because he has provided a clear description of Husserl's notion of retention, which I consider to be useful in discussing Fang's work. Fang has only dealt with a sphere of the life-world of everyday life rather than the whole of it. This sphere is the immediate present that organizes everyday experience into a whole of now-here. Yet in order for this now-here to make sense, there must a retentional-protentional horizon, an immediate past that is already part of the present and an immediate future that is also part of the present to set off the present. The so-called "non-event state" is precisely such a horizon of time. This is not saying that common people in the countryside could not record things past accurately - for example, what happened during the early years of the Maoist revolution; rather, when forced into a context of conver-

26 Carr 1986: 26. 
sation with those from outside their community, they make use of a particular kind of the past, a just-past-ness, as the background from which the present, so to speak, stands out. The effect of the Maoist power-practice lies in its success in re-shaping the very sense of the present by creating this new immediate past-ness. This was achieved, as Fang has shown, through a new habitus of "pouring out grievances." The present as now-here came to be constructed against a different background when the government sent their work teams to the countryside. What was transformed was not only the social structure but the way in which people made sense of and for themselves. The life-world of everyday life that Fang describes is this immediate surrounding of the present, which, under the Maoist government, came to be colored with bitterness and complaints about the past. "Pouring out grievances" became a crucial color on the canvas of everyday experience.

Fang's research and the Oral History Project in general have drawn our attention to the question of how Communist power-practice could be so effective in penetrating the corners of everyday life in a vast countryside with such diverse local traditions. Its effectiveness seems to have come from the Maoist government's success in transforming the everyday consciousness of now-here. This now-here, during the years of the Maoist revolution, constituted the bitterness and grievances poured out against the past. This sense of the past refers the past before the arrival of the Communist Party. What we have been discussing is another sense of the past, the immediate past, the just-past-ness that makes a now-here possible. This just-past-ness, which, according to Husserl, is an essential part of the present, was made of the grievances from which the Communist now-here stood out as the present moment of victory. This is to say that the Maoist victory is a victory in re-shaping the background of time-awareness. Through its mass movements and political campaigns, the Maoist government successfully installed, in the life-world of everyday life, a different mode of time-awareness, in which the present was intrinsically made in contrast to a miserable past. The horizon of the present was changed. "Pouring out grievances," as a strategy of telling stories about the past supported and carried out by political movements, resulted in the transformation of the retentional domain of time-awareness in the life-world of everyday life into a darker color, which was meant to contrast with the brightness of the present. Therefore, rather than thinking that the life world of everyday life is a chunk of non-events which cannot be organized by 
common people in any meaningful sequence in time, as Fang seems to have suggested, I am arguing that the so-called "non-event state" is not the characteristic state of the life-world of everyday life in the countryside; instead, it is the experiential surface, the face of the actual world of experience in daily life, through which a mode of time-awareness, defined as a relation of past-present-future for being in the world, comes into expression. My argument is not that common people in the countryside resisted the intrusion of the Communist power-practice, whether successfully or not, that resulted in the creation of a "non-event state," but that the effectiveness of the Communist power-practice lay in its success in creating a new temporal horizon that allowed an always-glorious present always to stand out against the background of a painful past.

If one reads Fang's work with patience, one will probably find that a double possibility of interpreting her meaning. Fang seems to be saying that the non-event state is a state of the life-world of everyday life, which in this sense would characterize more generally social life in oral communities; however, she also suggests, here and there, that the emergence of this non-event state was, at least partially, a result of the Communist power-practice in the countryside. Because people could not find proper ways of responding to the official inquisitions throughout the years of the Maoist revolution, they tended to hide what they really wanted to say from the outsiders. These two arguments coexist in Fang's work. To solve this contradiction, which has stimulated my own thinking, it seems to me that we must acknowledge the distinction between recollection and retention, whether we want to follow Husserl or not. To put it bluntly, the Communist power-practice in the countryside re-shaped the relationship of the present to the past; it created a new form of retentional memory, which differs from what was remembered by the act of recollection. Without such a distinction, Fang confuses the natural ability to remember (i.e., to recollect what happened in the past), with the historical production of a collective retention that colors the present in a certain way. 


\section{Further Remarks and Reflections}

Fang's analysis of Xicun peasants' understanding of time thus provides a possible entrance to several contemporary concerns. To extend our discussion of Husserl and Carr brings up the role of imagery in the making of retentional memories. If we understand retention as the immediate background for the present, and this background is a canvas of our awareness of time in the life-world of everyday experience, it is important to draw attention to the means by which such an awareness is produced. Fang's work seems to suggest that creating an image of something or someone is more effective than simply ordering the masses to follow the rules of revolution. This further implies that, because the life-world of everyday life is structured by repetition and redundancy, it is much easier to make an impression by images than with words. ${ }^{27}$ The distinction I wish to draw here is one between what may be called everyday awareness by words and the awareness produced by images. Verbal awareness, that is, based on words and sentences, is discrete and discontinuous. When someone says: I was beaten by the landlord, a total fact is given, as a whole and at once. However, everyday awareness made of images is of different nature. One difference is that memories made up of images, which cannot be said in a direct and easy way, draws what is remembered more towards the here-now. That is, when one tries to retrieve a scene of being beaten up by a landlord, what comes to one's mind is the fact of here-now as one's own mind pictures the scene. Verbal awareness creates some sort of distance in our awareness. When someone says that he was beaten by a landlord, he was giving this event a distance from himself as the center of here-now. It happened there and then, as linguistically structured. Image awareness, since it always revolves around a here-now, can never be purely "objective."

Of course, in any actual situation, these two modes of awareness are intertwined. Metaphor is image in words, for example. In the case of Xicun, however, images clearly seem to predominate over words. Words were controlled by a small group of villagers, but everyone else could maintain some

27 Metaphor is an image in words. See Wakeman 1973: 74-93 for a discussion of Mao Zedong's extraordinary capability for creating images for the masses at different stages of the revolution in China. 
images about what was said or told. It seems that the peasants largely learned to remember images of bitterness that were supposed to be attributed to the Old Society before the arrival of the Maoist revolution. Peasants did not read, but they heard and told stories about themselves and others, and these stories were full of images of bitterness.

The insights generated by this study have implications for how we should think about history. As is well known, various struggles all around the world in the present as much as the past, have rested on different understandings of history. For instance, China criticizes Japan for not apologizing for its war crimes half a century ago. Many regional ethnic conflicts are also linked to the different claims about the past, recent or remote. Is this simply a question about the historical truth? Is this simply a matter of identifying the good and the evil? No, because whatever actually happened in the past, different groups of people have developed their own ways of being in history - through different modes of memory. My discussion of Fang's work and the Oral History Project hopes to show that the present can be shaped in quite different ways depending on the making of the background of time-awareness that includes an immediate past and an immediate future. When we refer to memory, we first mean this immediate environment of our awareness from which we speak about our present concerns. This environment - this background, this horizon of our awareness - does not belong to an objective domain of recollecting memorable events in the past; instead, it is the being of history itself, subjective only in the sense that it is the way of our being in the world. Misunderstandings of others often result from the tendency to assume that one's own horizon of time-awareness is the only (or only correct) way of being in history. It is not what we say; it is the way in which we allow the present to stand out from its immediate environment of concerns that establishes different political claims about history. 
References cited

Bloch, M. (1975), Political language and oratory in traditional society. London: Academic Press.

Carr, D. (1986), Time, narrative, and history. Bloomington: Indiana University Press.

Chan, A., R. Madsen, and J. Unger (1992), Chen Village under Mao and Deng. Berkeley: University of California Press.

Crook, I., and D. Crook (1979), Mass movement in a Chinese village: Ten Mile Inn. London: Routledge and Kegan Paul.

Elias, N. (1992), Time: An essay. Oxford: Blackwell.

Fang Huirong 方慧榮 (1997), “Wu shïian jing” yu shenghuo shijie zhong de “zhenshi”: Xicun nongmin tudi gaige shiqi shehui shenghuo de jiyi “無事件 境” 與生活世界中的 “真實”：西村農民土地改革時期社會生活 的記憶 ("Non-Event State" and "Truth" in the Life- World: Memories of Social Life of Xicun Peasants during the Period of Land Reform). Research Center for Oral History of Social Life, Peking University.

Goody, J. ed. (1968), Literacy in traditional societies. Cambridge: Cambridge University Press.

Hallpike, C. R. (1979), The foundations of primitive thought. Oxford: Clarendon.

Hinton, W. 1966. Fanshen: A documentary of revolution in a Chinese village. New York: Monthly Review.

Husserl, E. (1964), The phenomenology of internal time-consciousness. Trans., J. S. Churchill. Bloomington: Indiana University Press.

Jing, J. (1996), The temple of memories: History, power and morality in a Chinese village. Stanford: Stanford University Press.

Merleau-Ponty, M. (1962), Phenomenology of perception. Trans. C. Smith. London: Routledge \& Kegan Paul.

Ong, W. (1982), Orality and literacy: The technologizing of the word. London: Routledge.

Potter, S. H., and Potter J. (1990), China's peasants: The anthropology of a revolution. Cambridge: Cambridge University Press.

Rawski, E. S. (1988), "A historian's approach to Chinese death ritual”, in Watson, J. L. and Rawski, E. S. eds. (1988), Death Ritual in Late Imperial 
and Modern China. Berkeley: University of California Press, 20-34.

Sokolowski, R. (2000), Introduction to phenomenology. Cambridge: Cambridge University Press.

Spiegelberg, H. (1982), The phenomenological movement: A historical introduction. Hague: Kluwer ( $3^{\text {rd }}$, rev. ed.).

Wakeman, F. (1973), History and will: Philosophical perspectives of Mao Tse-Tung's thought. Berkeley: University of California Press.

Watson, J. L. (1988), "The structure of Chinese funeral rites: Elementary forms, ritual sequence, and the primacy of performance", in Watson, J. L. and Rawski, E. S. eds. (1988), Death Ritual in Late Imperial and Modern China. Berkeley: University of California Press, 3-19.

Wilson, B. R. (1970), Rationality. Oxford: Basil Blackwell.

Yan, Y-X. (1996), The flow of gifts: Reciprocity and social networks in a Chinese village. Stanford: Stanford University Press. 